\begin{tabular}{|c|c|}
\hline Відомості про автора: & Information about the author: \\
\hline $\begin{array}{l}\text { Гапонова Людмила Юріївна - аспірант, викладач, } \\
\text { Національний університет фізичної культури та } \\
\text { спорту (Київ, Україна) }\end{array}$ & $\begin{array}{l}\text { Haponova Liudmyla Yuriivna - PhD student, } \\
\text { lecturer, National University of Ukraine on Physical } \\
\text { Education and Sport (Kyiv, Ukraina) }\end{array}$ \\
\hline $\begin{array}{l}\text { e-mail: luda.haponova@gmail.com } \\
\text { https://orcid.org/0000-0003-1699-2334 }\end{array}$ & \\
\hline
\end{tabular}

\section{УДК 796.035-053.81:572.511 doi: 10.15330/fcult.34.130-138}

\section{Igor Vypasniak, Iryna Ivanyshyn}

\title{
CORRECTION AND PROPHYLACTIC TRENDS IN PHYSICAL TRAINING OF ADULTS
}

\begin{abstract}
Мета дослідження: на підставі теоретичного аналізу $і$ власних експериментальних досліджень науково обтрунтувати, розробити теоретико-методичні засади концепції корекційно-профілактичних технологій у фізичному вихованні осіб з функціональними порушеннями опорно-рухового апарату для підвищення його здоров'яформуючої спрямованості. Для вирішення поставлених завдань було використано такі методи дослідження: теоретичні (аналіз спеціальної науково-методичної літератури, документальних матеріалів), соціологічні (інтерв'ю й опитування), емпіричні (педагогічне спостереження, педагогічне тестування фізичних якостей різних груп м'язів), біомедичні (метод В. Бунака в модифікації Е. Мартиросова, розрахунок індексу Піньє для визначення типу тілобудови, метод фотографії й аналізу статури з використанням програми “Тогsо”, експрес-метод візуального скринінгу біогеометричного профілю), методи математичної статистики. Результати. У процесі досліджень розроблено концепцію профілактики $і$ корекиї функціональних порушень опорно-рухового апарату осіб зрілого віку в процесі фізичного виховання, відмінними особливостями якої $\epsilon$ побудова методології управління з урахуванням індивідуальних особливостей стану біогеометричного профілю їх постави, щчо включає теоретичну $i$ практичну складові. Практична складова включала корекційно-профілактичні технології. Висновки. Нами розроблено профілактично-корекційні технології для осіб з функціональними порушеннями ОРА. Мета технологій - впровадження корекиійно-профілактичних заходів оздоровчого спрямування, щзо мають за мету корекцію функціональних порушень ОРА, фізичного стану осіб зрілого віку під дією фізичного навантаження, враховуючи рівень ӥх біогеометричного профілю постави.
\end{abstract}

Ключові слова: особи зрілого віку, функиіональні порушення опорно-рухового апарату, тілобудова, профілактика, корекція, фізичне виховання.

The purpose of the work is on the basis of theoretical analysis and own experimental research, to scientifically substantiate, develop theoretical and methodological foundations of corrective-preventive technologies concept in physical training of adults with MSS functional disorders in order to improve their health-forming orientation. Methods. The analysis and synthesis of scientific and methodological literature and Internet sources data were carried out with the purpose to establish work priority directions, determine problematic questions on prevention and correction of MSS functional disorders of adults in the process of physical training. Sociological research methods (interview and questionnaire). Empirical research level (pedagogical observation, pedagogical physical fitness testing that is the determination of general endurancelevel, strength endurance of torso muscles, force endurance of upper extremities and backmuscles, spinal column flexibility, movements speed development, hip joints mobility and hamstrings elasticity, movements static body balance; pedagogical experiment). Biomedical methods (anthropometry - examination of adult persons was carried out by standard equipment according to the conventional and unified methods of $V$. Bunak in the modification of E. Martirosov, using the Pinnier index was determined the type of body structure; photography and posture analysis of students was done using the "Torso" program; visual screening of the posture biogeometric profile was carried out with the help of express control card. Results. During research there was developed the prevention and correction concept of musculoskeletal system functional disorders of adults in physical education process, distinctive features of which is the management methodology construction, taking into account the individual features of their' posture biogeometric profile, including theoretical and practical components. The practical component included corrective and prophylactic technologies. Conclusions. For theoretical concept provisions realization, we have developed prevention and correction technologies of MSS functional disorders of adults in physical training process. The purpose of technology is justification and implementation of correctivepreventive measures aiming at correction of MSS functional disorders, students physique in physical training process taking into account their biogeometric profile level to improve its health-forming orientation.

Keywords: adults, musculoskeletal system, posture functional disorders, correction, physical education. 
Introduction and analysis of recent researches. Caring about young generation health is an urgent problem in modern society $[1,4,8,14]$. The deterioration of student youth health poses a serious social risk. In the context of modern trends of social and economic development, educational paradigms modernization, which in aggregate predetermine innovative processes in higher education, becomes of particular importance. Numerous studies conducted in recent years $[1,2,11,13]$ confirm the mass character of musculoskeletal system (MSS) functional disorders of students. Due to urgency of the problem, Ukrainian specialists have substantiated various innovative technologies, methods and programs for the prevention and correction of MSS functional disorders of student and adults [3, 5, 7, 11]. Itshould be noted the work of A. Alyoshina [1], which substantiates the concept of prevention and correction of MSS functional disorders of children and young people in the process of physical education. At the same time, the tendency of increasing number of students with MSS functional disorders shows that the scientific and methodological providing of work with this category of people is falling far behind time requirements and have further need for methodological, organizational and practical substantiation.

The purpose of the work is on the basis of theoretical analysis and own experimental research, to scientifically substantiate, develop theoretical and methodological foundations of corrective-preventive technologies concept in physical training of adults with MSS functional disorders in order to improve their health-forming orientation (on the basis of students sample).

Research materials and methods. The analysis and synthesis of scientific and methodological literature and Internet sources data were carried out with the purpose to establish dissertation work priority directions, substantiate theoretically object and subject of research, determine problematic questions on prevention and correction of MSS functional disorders of students in the process of physical education. Theoretical analysis of scientific and methodological literature data (analysis and synthesis, generalization, induction and deduction) made it possible to determine the main directions of research issues, its relevance, purpose andtasks. Sociological research methods (interview and questionnaire). Empirical research level (pedagogical observation, pedagogical physical fitness testing that is the determination of general endurancelevel, strength endurance of torso muscles, force endurance of upper extremities and backmuscles, spinal columnflexibility, movements speed development, hip joints mobility and hamstrings elasticity, movements static body balance; pedagogical experiment). Biomedical methods (anthropometry - examination of adults was carried out by standard equipment according to the conventional and unified methods of V. Bunak in the modification of E. Martirosov, using the Pinnier index was determined the type of students' body structure; photography and posture analysis of students was done using the "Torso" program; visual screening of the posture biogeometric profile was carried out with the help of express control card [11]. The method of expert evaluation was used during the expert evaluation ofcertain factors importance by determining their rank in descending order of importance (preference method); in mathematical statistics methods we used descriptive statistics, sampling method, factor analysis we used to study the factor structure of physical development, physique and state of biogeometric student posture profile.

Results and discussion. According to obtained data, only $33.0 \%$ of first-year students have a normal posture. At the same time, we found negative tendency of reducing the numberof students with normal posture from the first to the fourth year: in the second year the number of students with a normal posture was already $28.8 \%$, in the third year $-21.6 \%$, in the fourth year - only $19.8 \%$. Such postural disorders as "scoliotic posture" and "round back" herewith dominated. 
The visual screening results of students' posture helped to determine its biogeometric profilelevel. First of all, $71.1 \%$ of the first-year students with normal posture were characterized by a high level of biogeometric posture profile, and $28.9 \%$-by average (Table 1).

The negative tendency of reducing students posture biogeometric profile level from year to year has been established.

According to test exercises results, which characterize the spine flexibility, hip joints mobility and the hamstrings elasticity, upper extremities and backstrength endurance, body muscles strength endurance, the strength endurance of forearm flexor smuscles, static body balance, in first-year students with normal posture for the number of indicators there was observed a significant differences compared tothe data of students with different MSS functional disorders and low posture biogeometric profile level $(\mathrm{p}<0,05)$.

Table 1

Distribution of students according toposture biogeometric profile level, \%

\begin{tabular}{|c|c|c|c|c|c|}
\hline \multirow{2}{*}{$\begin{array}{c}\text { Posture } \\
\text { biogeometric } \\
\text { profile level }\end{array}$} & $\begin{array}{c}\text { Normal } \\
\text { posture }\end{array}$ & Flatback & Rounded back & Roundback & Scolioticposture \\
\cline { 2 - 6 } & $\mathrm{n}=38$ & $\mathrm{n}=11$ & $\mathrm{n}=10$ & $\mathrm{n}=13$ & $\mathrm{n}=43$ \\
\hline 1-st year (n=115) & - & 36,4 & 30,0 & 46,2 & 27,9 \\
\hline low & 28,9 & 63,6 & 70,0 & 53,8 & 72,1 \\
\hline average & 71,1 & - & - & - & - \\
\hline high & $\mathrm{n}=31$ & $\mathrm{n}=9$ & $\mathrm{n}=9$ & $\mathrm{n}=15$ & $\mathrm{n}=44$ \\
\hline 2-nd year (n & - & 33,3 & 44,4 & 26,7 & 43,2 \\
\hline 108) & 58,1 & 66,7 & 55,6 & 73,3 & 56,8 \\
\hline low & 41,9 & - & - & - & - \\
\hline average & $\mathrm{n}=21$ & $\mathrm{n}=5$ & $\mathrm{n}=7$ & $\mathrm{n}=16$ & $\mathrm{n}=48$ \\
\hline high & - & 80,0 & 71,4 & 50,0 & 47,9 \\
\hline 3-rdyear (n=97) & 66,7 & 20,0 & 28,6 & 50,0 & 52,1 \\
\hline low & 33,3 & - & - & - & - \\
\hline average & $\mathrm{n}=16$ & $\mathrm{n}=6$ & $\mathrm{n}=6$ & $\mathrm{n}=10$ & $\mathrm{n}=43$ \\
\hline high & - & 66,7 & 100,0 & 90,0 & 58,1 \\
\hline 4-thyear (n=81) & 68,8 & 33,3 & - & 10,0 & 41,9 \\
\hline low & 31,2 & - & - & - & - \\
\hline average & & & & \\
\hline high & & & & \\
\hline
\end{tabular}

According to obtained data,in first-year students with normal posture and high biogeometric profile posture level the torso angle $\left(\alpha_{2}\right)$ was on average equal $(1.66 \pm 0.57)^{0}$, in third-year students this indicator was statistically higher $(2.25 \pm 0.63)^{0}$, and in fourth-year students it was on average $(2.49 \pm 0.32)^{0}(\mathrm{p}<0.05)$.

The calculations prove that the asymmetry blades angle $\left(\alpha_{6}\right)$ had the following average indicators $(\bar{x} \pm s)$ : in first-year students $-(1.92 \pm 0.41)^{0}$, that is significantly statistically less $(\mathrm{p}<0.05)$ than in third-year students $(2.47 \pm 0.58)^{0}$ and fourth-year students $-(2.76 \pm 0.42)^{0}$.

It should also be noted that the comparative characteristics of students data with normal posture and students with scoliotic posture and round back showed statistically significant differences $(p<0,05)$ between the values $(p<0,05)$ of goniometry indices of their body, indicating the negative tendency to students angular characteristics deterioration from course to course.

During the pedagogical experiment, we distributed the students of 1-4 courses by physique type. It was found that the most students had mesomorphic somatotype at each 
course (in the1st year $-63.41 \%$; 2nd year $-58.82 \%$; 3rd year $-60.08 \%$; 4th year $-60.38 \%$ ); $14.63 \%$ of 1 st year students, $15.69 \%$ of 2 nd year students, $15.87 \%$ of 3rd year students and $18.87 \%$ of 4 th year students had ectomorphic somatotype; $21.95 \%$ of 1 st year students, $25.49 \%$ of 2 nd year students, $19.05 \%$ of 3 rd year students, $20.75 \%$ of 4 th year students had endomorphic somatotype.

The distribution of 1st year students according to posture type indicated that normal posture was observed in $11.76 \%$ of ectomorphic somatotype students. Posture distribution of students of this type was as follows: $11.76 \%$ of students with rounded and flat back, $29.41 \%-$ round back, and 35.29\% - scoliotic posture (Fig. 1).

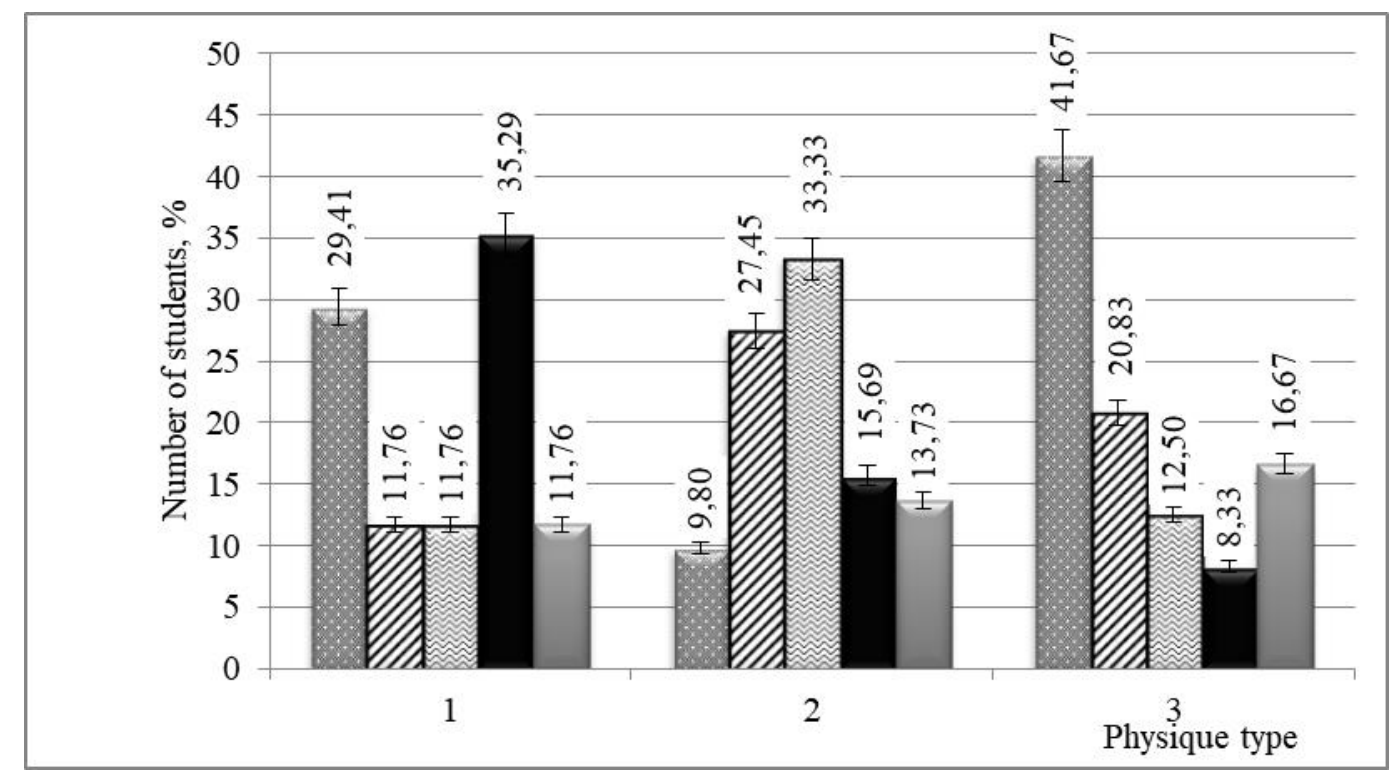

Fig 1. Distribution of 1st year students with different body structure according to revealed functional postural disorders $(n=92)$ :

- roundback; $\mathbb{Z}$ - normal posture; $\square$ - rounded back; $\square_{\text {- flat back; }} \square$ - scoliotic posture; 1 - ectomorphic type, 2 - mesomorphic type; 3 - endomorphic type

In the experimental study it was determined that among students of mesomorphic somatotype normal posture was observed in $27,45 \%, 9,8 \%$ of students had round back, $33,33 \%$ - rounded back, $15,69 \%$ - scoliotic posture, and $13.73 \%$ - flat back. It should be noted that in endomorphic somatotype students the most had round back $-41.67 \%$. At the same time, $20.83 \%$ of students had normal posture, $12.50 \%$ - rounded back, $16.67 \%$ - flat back, and $8.33 \%$ had scoliotic posture.

During further research, we determined the state of students' biogeometric profile, depending on their posture and structure type. The distribution of 1 st year students with different body structure according to their posture biogeometric profile level made it possible to establish that students with normal posture had ahigh level, students with rounded back and scoliotic posture were usually characterized by low, and with round and flat-by average posture biogeometric profile level.

During the study there were observed physical fitness peculiarities of students of different physique depending on the posture violations. It should be noted that students with endomorphic flat-back somatotype had the lowest value of indicatorsof physical fitness compared to students of other physique types and postural disorders.

For theoretical concept provisions realization, we have developed prevention and correction technologies of MSS functional disorders of youth in physical training process (Fig. 2) 
The purpose of technology: justification and implementation of corrective-preventive measures aiming at correction of MSS functional disorders, students physique in physical training process taking into account their biogeometric profile level to improve its health-forming orientation.

Tasks of technology:

1. Increasing the efficiency of physical training process in the direction of MSS functional disorders correction, students physique taking into account their biogeometric profile level.

2. Increasing the biogeometric profile level of students posture with MSS functional disorders and different physique types.

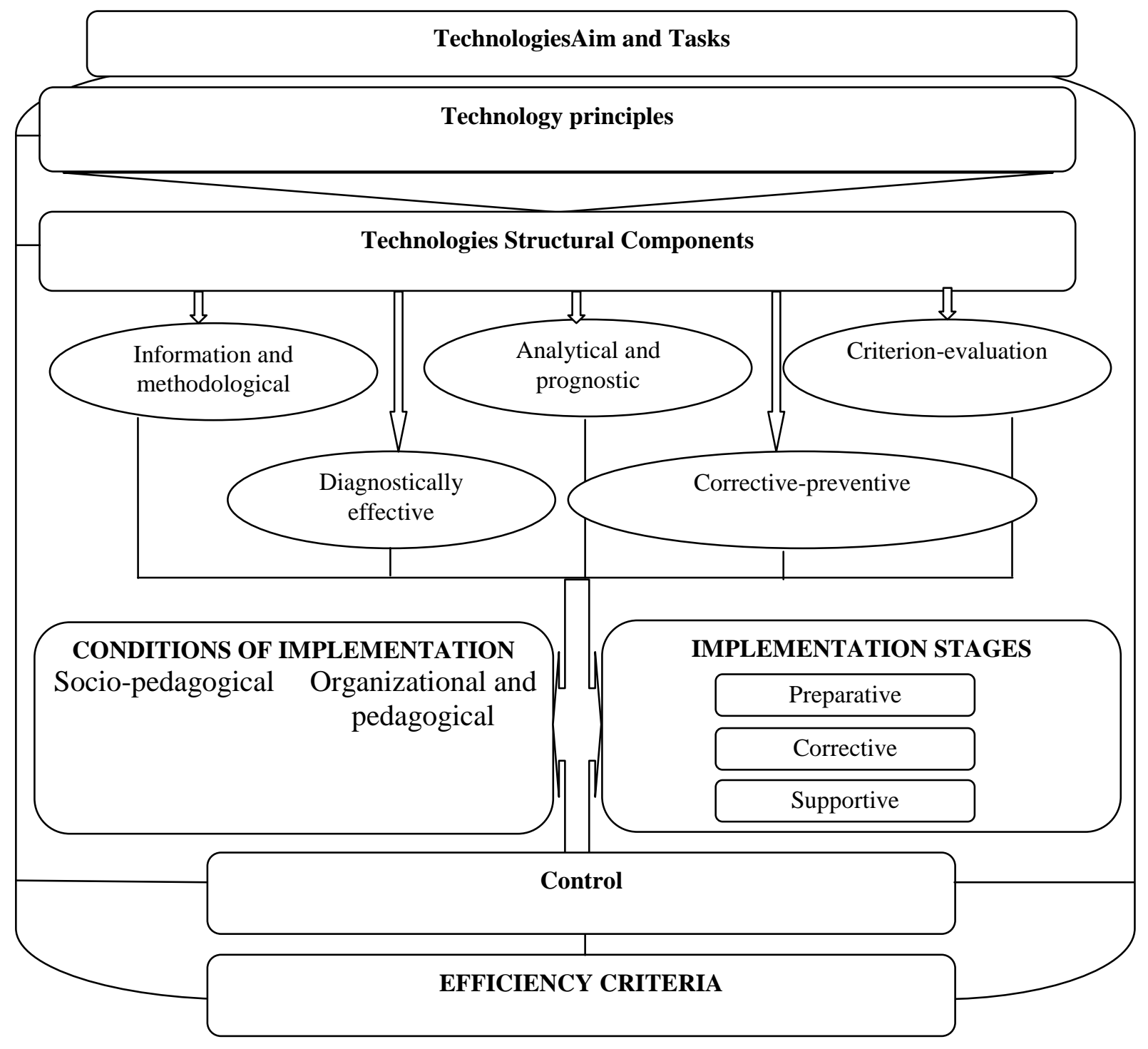

Fig. 2. Flowchart of Corrective-Prophylactic Technologies of Physical Training of Students with MSS Functional Disorders

3. Increasing the physical development and physical qualities level of students with MSS functional disorders and different physique types through modern athletic gymnastics means in physical training process.

4. Form a clear motivational orientation and reinforce the students' persistent need for regular exercise. 
5. Increasing students'theoretical knowledge level and practical skills of health technologies using in the direction of physique correction and MSS functional disorders.

The correct biogeometric posture profile is considered by us in the context of students harmonious physical development, and any violation of it is the first indicator of changes in different human body systems functioning. According to the scientific community [10] deviationof physique components from optimal values negatively influences both physical and mental student youth status.

In literature both in Ukraine and abroad, there are quite a lot practical developments concerning the problem of students physique correction in physical training process. Scientific researches analysis on the above mentioned socially important problem has shown that, despite considerable attention of experts, there was reviewed insufficient development of students physique correction technologies in physical training process taking into account posture biogeometric profile level. The above problem is compounded by the fact that posture functional disorders are among the most common abnormalities in student youth musculoskeletal system.

Scientific literature analysis showed $[6,9,10]$ that the problem of theoretical substantiation of prevention and correction concept of MSS functional disorders of youth in physical training process, taking into account biogeometric posture profile was not the subject of domestic and foreign scholarswide range studies andinsufficiently researched in pedagogical theory

Despite considerable theoretical achievements in the sphere ofprevention and correction of MSS functional disorders of youth, the question of theoretical and methodological substantiation of corrective-preventive measures of above mentioned contingent taking into posture biogeometric profile level and physique type is not explored enough.

The ascertainment experiment data showed that traditional pedagogical tests use to assess functional MSS status of studentswas not sufficiently informative, but only attested general negative tendency to individual physical qualities level decrease. However, additional pedagogical tests, for examplethe Flamingo test for assessing the students' bodies vertical resistance, showed statistically significant differences between testing results of first-year students compared to2-3-year students $[12,13]$. This was taken into account whileplanning the forming experiment.

Conclusions. For the first time there was substantiated the prevention and correction concept of musculoskeletal system functional disorders of student youth in physical training process, distinctive features of which is the management methodology construction, taking into account the individual features of students' posture biogeometric profile, including theoretical and practical component. The practical component included corrective and preventive technologies.

The technology of students posture correction taking into account the detected state of its biogeometric profile includes three stages - preparatory, corrective and supportive, each of which solved the appropriate tasks and provided fifteen complexes of differently orientated exercises. The criteria of technology effectiveness include analysis of posture biogeometric profile level, body goniometry indicators and students physical fitness. An integral part of the developed technology is pedagogical control, which allows to observe, measure and evaluate the indicators of posture biogeometric profile, body goniometry, as well as physical preparedness of students in physical training process.

The technology of students structure correction in physical training process taking into account the state of their posture biogeometric profile level is based on the following structural components: orgatnizational, diagnostic, methodological, control and correction, informational and resultative. The technology consists of preparatory, corrective, supportive stages, includes 5 blocks of physical exercises and information-methodological system 
"Perfectum corpus". The multimedia informational-methodical system "Perfectum corpus" has been developed to increase students' theoretical knowledge level and their motivation to exercise. The multimedia information and methodological system content is a structured amount of knowledge, consisting of pre-selected material in the form of separate modules. Theoretical module "Useful to Know" includes the following information: "Healthy Lifestyle","A healthy body makes a healthy spirit" and "Monitoring". The module "Practice" contains data of athletic gymnastics means using, taking into account body type and students posture biogeometric profile state. The multimedia information and methodological system "Perfectum corpus" allows to integrate different types of information supply namely text, static and dynamic graphics, videos into a single complex, which allows student to become an active participant in physical training process. Bonus module of multimedia information and methodological system includes the following elements: "Interesting videos", "Internet resources", "Types of motor activity".

The implementation of technologies can be carried out according to the following algorithm:

- the first algorithm step: analysis of corrective and preventive measures structure; definition of indicators of physical development and physical fitness, body type; screening of posture biogeometric profile level, indicators of students musculoskeletal system formation; definition of means, methods of physical training; informing students about research results; characterization of exercises, size and orientation of load, forms of students' classes organization; conditions of implementation;

- the second step: planning of corrective and preventive measures, development of training programs in athletic gymnastics, content substantiation of exercise complexesof different biomechanical orientation;

- the third step: the experimental verification of influence of correction technologies means and methods on MSS functional disorders, the state level of posture biogeometric profile, students physique and physical fitness;

- the fourth step: development of practical recommendations on modern correctivepreventive technologies use taking into account the students' motives.

Prospects for further research. The further research prospects are related to scientifically proven program development of student physique correction, taking into account posture biogeometric profile level.

1. Альошина А. І. Профілактика й корекція порушень опорно-рухового апарату в дошкільнят, школярів та студентської молоді у процесі фізичного виховання. Луцьк : Вежа-Друк, 2015. 368 с.

2. Винтоняк О. В., Лопацкий С. В. Нарушения осанки студентов в процессе физического воспитания на современном этапе, как научная проблема. Revistăteoretico-tiinţifică "Stiinţa culturi i fizice". Кишинев, 2016; 25/1:84-89.

3. Випасняк Ігор, Лопацький Сергій, Лісовський Богдан. Корекція порушень постави студентів у процесі фізичного виховання 3 урахуванням стану біогеометричного профілю. Науковий часопис національного педагогічного університету імені М.П. Драгоманова. Серія №15. "Науково-педагогічні проблеми фізичної культури / фізична культура і спорт”: зб. наукових праць. Київ: Вид-во НПУ імені М.П. Драгоманова. 2016; 78К: 50-54.

4. Кашуба В., Футорный С., Хабинец Т., Лопацкий С. К вопросу повышения эффективности физического воспитания занимающихся физическими упражнениями с использованием технологических инноваций. Молодіжний науковий вісник Східноєвропейського національного університету імені Лесі Українки. Фізичне виховання і спорт / уклад. А. В. Цьось, А. І. Альошина. Луцьк : Східноєвроп. нац. ун-т ім. Лесі Українки. 2017; 27: 46-53.

5. Лопацький С. В., Випасняк І. П., Вінтоняк О. В. Аналіз корекційно-профілактичних технологій використовуваних у процесі фізичного виховання студентів з функціональними порушеннями опорнорухового апарату. Вісник Прикарпатського університету. Серія : Фізична культура. 2016; 23: 3-11. 
6. Kashuba, V., Golovanova, N. Increase in efficiency of professionally applied physical training of pupils of 16-17 years old based on application of informational and methodicals sytems. Physical education of students. 2018; 22(2):57-62.

7. Ivanchykova, S., Saienko, V., Goncharova, N., Tolchieva, H., \&Poluliashchenko, I. Comparative analysis of changes in the body composition of female students under the influence of the various kinds of fitness training load. Journal of Physical Education and Sport. 2018; 18(2): 961-65.

8. Kashuba, V., Futornyi, S., Andrieieva, O., Goncharova, N., Carp, I., Bondar, O. \&Nosova, N. Optimization of the processes of adaptation to the conditions of study at school as a component of health forming activities of primary school-age children. Journal of Physical Education and Sport. 2018; 18(4): 2515-21. doi: 10.7752/jpes.2018.04377.

9. Kashuba, V., Khmelnitska, I. \&Krupenya, S. Biomechanical analysis of skilled female gymnasts' technique in «round-off, flic-flac» type on the vault table. Journal of Physical Education and Sport, 2012; 12(4): 43135. doi: 10.7752/jpes.2012.04064.

10. Kashuba, V., Kolos, M., Rudnytskyi, O., Yaremenko, V., Shandrygos, V., Dudko, M. \& Andrieieva, O. Modern approaches to improving body constitution of female students within physical education classes. Journal of Physical Education and Sport. 2017; 17(4): 2472-76. doi: 10.7752/jpes.2017.04277.

11. Kashuba, V., Usychenko, V. \&Bibik, R. The modern approaches to correction of postural abnormalitiesthrough health-enhancing fitness in women of early adulthood. Sportyvnyi visnyk Prydniprovia, 2016a; 3: 64-71.

12. Yarmak, O., Galan, Y., Hakman, A., Dotsyuk, L., Blagii, O. \&Teslitskyi, Yu. The Use of ModernMeans of Health Improving Fitness during the Process of Physical Education of Student Youth. Journal ofPhysical Education and Sport. 2017a; 17 (3): 1935-40. doi:10.7752/jpes.2017.03189.

13. Shankovsky, A.,Vypasniak, I. On the Use of Information Technologies in the Process of Physical Education of Student Youth. Journal of Education, Health and Sport. 2017; 7(6): 902-17. http://www.ojs. ukw.edu.pl/index.php/johs/article/view/5077.

14. Vypasniak, I., Shankovsky, A. To the issue of increasing the efficiency of the process of physical education of student youth. Journal of Education, Health and Sport. 2017; 7(11): 340-51. http://www.ojs. ukw.edu.pl/index.php/johs/article/view/5230.

\section{References}

1. Aloshyna A. I. Profilaktyka y korektsiia porushen oporno-rukhovoho aparatu v doshkilniat, shkoliariv ta studentskoi molodi u protsesi fizychnoho vykhovannia. Lutsk : Vezha-Druk, 2015. $368 \mathrm{~s}$.

2. Vyntoniak O. V., Lopatskyi S. V. Narushenyia osanky studentov v protsesse fyzycheskoho vospytanyia na sovremennom эtape, kak nauchnaia problema. Revistăteoretico-tiinţifică "Stiinţa culturi i fizice". Kyshynev, 2016; 25/1: 84-89.

3. Vypasniak Ihor, Lopatskyi Serhii, Lisovskyi Bohdan. Korektsiia porushen postavy studentiv u protsesi fizychnoho vykhovannia $\mathrm{z}$ urakhuvanniam stanu bioheometrychnoho profiliu. Naukovyi chasopys natsionalnoho pedahohichnoho universytetu imeni M.P. Drahomanova. Seriia №15. "Naukovo-pedahohichni problemy fizychnoi kultury / fizychna kultura i sport": zb. naukovykh prats. K.: Vyd-vo NPU imeni M.P. Drahomanova. 2016; 78K: 50-54.

4. Kashuba V., Futornyi S., Khabynets T., Lopatskyi S. K voprosu povyshenyia effektyvnosty fyzycheskoho vospytanyia zanymaiushchykhsia fyzycheskymy uprazhnenyiamy s yspolzovanyem tekhnolohycheskykh ynnovatsyi. Molodizhnyi naukovyi visnyk Skhidnoievropeiskoho natsionalnoho universytetu imeni Lesi Ukrainky. Fizychne vykhovannia i sport / uklad. A. V. Tsos, A. I. Aloshyna. Lutsk : Skhidnoievrop. nats. unt im. Lesi Ukrainky. 2017; 27: 46-53.

5. Lopatskyi S. V., Vypasniak I. P., Vintoniak O. V. Analiz korektsiino-profilaktychnykh tekhnolohii vykorystovuvanykh u protsesi fizychnoho vykhovannia studentiv z funktsionalnymy porushenniamy opornorukhovoho aparatu. Visnyk Prykarpatskoho universytetu. Seriia : Fizychna kultura. 2016; 23: 3-11.

6. Kashuba, V., Golovanova, N. Increase in efficiency of professionally applied physical training of pupils of 16-17 years old based on application of informational and methodicals sytems. Physical education of students. 2018; 22(2):57-62.

7. Ivanchykova, S., Saienko, V., Goncharova, N., Tolchieva, H., \&Poluliashchenko, I. Comparative analysis of changes in the body composition of female students under the influence of the various kinds of fitness training load. Journal of Physical Education and Sport. 2018; 18(2): 961-65.

8. Kashuba, V., Futornyi, S., Andrieieva, O., Goncharova, N., Carp, I., Bondar, O. \&Nosova, N. Optimization of the processes of adaptation to the conditions of study at school as a component of health forming activities of primary school-age children. Journal of Physical Education and Sport. 2018; 18(4): 2515-21. doi: 10.7752/jpes.2018.04377. 
9. Kashuba, V., Khmelnitska, I. \&Krupenya, S. Biomechanical analysis of skilled female gymnasts' technique in 《round-off, flic-flac» type on the vault table. Journal of Physical Education and Sport, 2012; 12(4): 43135. doi: 10.7752/jpes.2012.04064.

10. Kashuba, V., Kolos, M., Rudnytskyi, O., Yaremenko, V., Shandrygos, V., Dudko, M. \& Andrieieva, O. Modern approaches to improving body constitution of female students within physical education classes. Journal of Physical Education and Sport. 2017; 17(4): 2472-76.doi: 10.7752/jpes.2017.04277.

11. Kashuba, V., Usychenko, V. \&Bibik, R. The modern approaches to correction of postural abnormalitiesthrough health-enhancing fitness in women of early adulthood. Sportyvnyi visnyk Prydniprovia, 2016a; 3: 64-71.

12. Yarmak, O., Galan, Y., Hakman, A., Dotsyuk, L., Blagii, O. \&Teslitskyi, Yu. The Use of ModernMeans of Health Improving Fitness during the Process of Physical Education of Student Youth. Journal ofPhysical Education and Sport. 2017a; 17 (3): 1935-40. doi:10.7752/jpes.2017.03189.

13. Shankovsky, A.,Vypasniak, I. On the Use of Information Technologies in the Process of Physical Education of Student Youth. Journal of Education, Health and Sport. 2017; 7(6): 902-17. http://www.ojs.ukw.edu.pl/ index.php/johs/article/view/5077.

14. Vypasniak, I.,Shankovsky, A. To the issue of increasing the efficiency of the process of physical education of student youth. Journal of Education, Health and Sport. 2017; 7(11): 340-51. http://www.ojs.ukw.edu.pl/ index.php/johs/article/view/5230.

Цитування на цю статтю:

Vypasnyak I, Ivanyshyn I. Correction and prophylactic trends in physical training of adults. Bicник Прикарпатського університету. Серія: Фізична культура. 2019 Листоп 27; 34: 130-138

\begin{tabular}{|c|c|}
\hline Відомості про автора: & Information about the author: \\
\hline $\begin{array}{l}\text { Випасняк Ігор Петрович - доктор наук з фізич- } \\
\text { ного виховання і спорту, професор, ДВНЗ } \\
\text { "Прикарпатський національний університет імені } \\
\text { Василя Стефаника" (Івано-Франківськ, Україна) }\end{array}$ & $\begin{array}{l}\text { Vypasnyak Ihor - Doctor of Science in Physical } \\
\text { Education and Sports, Professor, Vasyl Stefanyk } \\
\text { Precarpathian National University (Ivano-Frankivsk, } \\
\text { Ukraine) }\end{array}$ \\
\hline \multicolumn{2}{|l|}{$\begin{array}{l}\text { e-mail: kicuk80@gmail.com } \\
\text { https://orcid.org/0000-0002-4192-1880. }\end{array}$} \\
\hline $\begin{array}{l}\text { Іванишин Ірина Мирославівна - кандидат хіміч- } \\
\text { них наук, доценТ, ДВНЗ“Прикарпатський націо- } \\
\text { нальний університет імені Василя Стефаника” } \\
\text { (Івано-Франківськ, Україна) }\end{array}$ & $\begin{array}{l}\text { Ivanyshyn Iryna-Candidate of Science (Chemistry), } \\
\text { Associate Professor (Ph. D.), Vasyl Stefanyk } \\
\text { Precarpathian National University (Ivano-Frankivsk, } \\
\text { Ukraine) }\end{array}$ \\
\hline $\begin{array}{l}\text { e-mail: Iraivan68@ gmail.com } \\
\text { https://orcid.org/0000-0003-1765-8311 }\end{array}$ & \\
\hline
\end{tabular}

УДК 378.093.2.016:796.

doi: 10.15330/fcult.34.138-145 Вімалій Кашуба, Інна Асаулюк

\section{РІВЕНЬ СТАНУ БІОГЕОМЕТРИЧНОГО ПРОФІЛЮ ПОСТАВИ СТУДЕНТІВ В ПРОЦЕСІ ФІЗИЧНОГО ВИХОВАННЯ}

Інтенсифікація прочесу навчання, психічне насичення та недостатній обсяг рухової активності обумовлює недостатній рівень фізичного стану студентського контингенту загалом та слабкість м'язового корсету зокрема. У той же час робоча діяльність студентів спеціальності "Музичне мистецтво” характеризується малозручною робочою позою, яка провокує тривале напруження м'язового корсету та, відповідно, ряд порушень постави. В процесі дослідження виявлено особливості стану біогеометричного профілю постави студентів дівчат I-IV курсів мистецьких спеціальностей, наступних спеціалізацій: акторське мистецтво, кіно фотозйомка, теорія музики; вокал, хорове диригування; оркестрові духові та ударні інструменти, народні інструменти; фортепіано, оркестрові, струнні інструменти; хореографія. Встановлено, щзо залежно від курсу навчання рівень стану біогеометричного профілю постави дівчат має певні особливості. Найвищий процент осіб із низьким рівнем стану біогеометричного профілю постави у дівчат спеціалізації “Фортепіано, оркестрові, струнні інструменти”. Отримані результати являлись підгрунтям для розробки коррекційної технологї̈ із 